\title{
The literary and political activity of manuscript verse collectors
}

Joshua Eckhardt

Virginia Commonwealth University, jmeckhardt@vcu.edu

Follow this and additional works at: https://scholarscompass.vcu.edu/engl_pubs

Part of the Literature in English, British Isles Commons

copyright Joshua Eckhardt

\section{Recommended Citation}

Eckhardt, Joshua. " The literary and political activity of manuscript verse collectors." In Manuscript Verse Collectors and the Politics of Anti-Courtly Love Poetry. Oxford: Oxford University Press, 2008, Available from VCU Scholars Compass, http://scholarscompass.vcu.edu/engl_pubs/1.

This Book Chapter is brought to you for free and open access by the Dept. of English at VCU Scholars Compass. It has been accepted for inclusion in English Publications by an authorized administrator of VCU Scholars Compass. For more information, please contact libcompass@vcu.edu. 


\section{1 \\ The Literary and Political Activity of Manuscript Verse Collectors}

When he copied poems into his notebook, a student of St. John's College, Cambridge preserved a wealth of texts that have come to characterize the English Renaissance. He also, however, collected verses that make this famous literary period appear strange. In only the first few surviving leaves of his anthology, for instance, he offered an unfamiliar account of Elizabethan love poetry, in which lyrics from the royal court sharply contrast, even as they resonate with, erotic verse. In the first remaining text that he transcribed, Queen Elizabeth I regrets that she scorned her many suitors when she 'was fayre and younge and fauour graced' her. ${ }^{1}$ The series of Nicholas Breton's pastoral works that immediately follows the queen's poem features a song that was actually sung for her on progress, and which she liked so well that she ordered a repeat performance. ${ }^{2}$ In Breton's lyric, the shepherdess Phillida at first

1 Bodleian MS Rawl. poet. 85, fol. 1r (Verses made by the queine when she wast supposed to be in loue ${ }^{\text {th }}$ mountsyre.//When I was fayre and younge and fauour graced me'). Transcribed in Laurence Cummings, 'John Finet's Miscellany' (PhD diss., Washington University, 1960), 79. Steven May finds Queen Elizabeth I the most likely, yet not the certain, author of the poem, judging from this attribution and another to her in British Library MS Harley 7392, pt. 2, fol. 21v. The only other early modern ascription, in Folger MS V.a.89, p. 12, assigns it to Edward de Vere, seventeenth earl of Oxford. Queen Elizabeth I: Selected Works (New York: Washington Square Press, 2004), 26-27.

2 The printed account of the entertainment describes its performance:

On Wednesday morning, about nine of the clock, as her Maiestie opened a casement of her gallerie window, ther were three excellent Musitians, who being disguised in auncient countrey attire, did greet her with a pleasant song of Coridon and Phyllida, made in three parts of purpose. The song, as well for the worth of the Dittie, as for the aptnes of the note thereto applied, it pleased her Highnesse, after it had beene once sung, to command it againe, and highly to grace it with her chearefull acceptance and commendation.

The Honorable Entertainement gieuen to the Queenes Maiestie in Progresse, at Eluetham in Hampshire (London: Iohn Wolfe, 1591; STC 7583), sig. D2v. 
resists Corridon's advances ('He woulde loue and she woulde not'), recalling the coyness of the 'fayre and younge' Elizabeth who likewise denied her admirers. Phillida, however, avoids the mistake for which the queen repents just two leaves earlier in the manuscript, by finally acquiesing: 'Loue that had bene longe deluded/Was with kisses sweet concluded.' 3 By placing these complementary poems written by and for Elizabeth in such proximity, this manuscript verse collector exhibited love poetry that she approved. He also established, at the outset of his miscellany, the initial theme of the coy mistress.

He then varied or countered this theme by featuring, on the very next leaf, a poem about another initially resistant, but ultimately compliant, woman, who nevertheless proves quite distinct from the coy mistresses of court literature. The female speaker of this poem employs diction that recalls Breton's pastoral characters (who say, 'Yea, and nay, and faythe and trouthe'), as she responds in graphic detail to a man while he coerces her to have sex. She begins the poem by protesting:

Naye, phewe nay pishe? nay faythe and will ye, fye.

A gentlman deale thus? in truthe ille crye.

Gods bodye, what means this? naye fye for shame

Nay, Nay, come, come, nay faythe yow are to blame.

Harcke sombodye comes, leaue of I praye

When such verbal resistance fails, the speaker threatens to resist physically: 'Ile pinche, ille spurne, Ile scratche.' Yet she soon turns attention from her own actions to those of the man:

You hurt marr my ruffs, you hurte my back, my nose will bleed

Looke, looke the doore is open some bodye sees,

What will they saye? nay fye you hurt my knees

Your buttons scratche, o god? what coyle is heere?

You make me sweate, in faythe here is goodly geare

Nay faythe let me intreat leue if you lyste

Yow marr the bedd, you teare my smock, but had I wist,

So muche before I woulde haue kepte you oute.

After completing the couplet with another line in the present tense ('It is a very proper thinge indeed you goo aboute'), the speaker changes tense

3 Bodleian MS Rawl. poet. 85, fol. 3r ('In the merye monthe of Maye'); Cummings, 'John Finet's Miscellany,' 95. 
to place the sexual encounter in the past: 'I did not thinke you woulde haue vsed me this./But nowe I see to late I tooke my marke amysse.' She concludes the monologue tending to the man and to the future of her relationship with him:

A lytle thinge woulde mak vs two not to be freends. You vse me well, I hope yow will make me amends. Houlde still Ile wype your face: you sweat amayne You have got a goodlye thinge $\mathrm{w}^{\text {th }}$ all this payne. O god how whott I am come will you drincke Ife ${ }^{\text {we }}$ goe sweatinge downe what will they thinke Remmember I praye howe you haue vsde me nowe Doubte not ere longe I will be quite with you. Ife any one but you shoulde vse me so Woulde I put vp this wronge? in faythe sir no Nay goe not yet: staye supper here with me Come goe to cardes I hope we shall agree. ${ }^{4}$

Like the courtly mistresses who came literally before her in this manuscript verse miscellany, the speaker of the monologue first denies her suitor. And like Corridon, the speaker's silent but active lover eventually has his way. Despite these similarities, however, most would have considered this sexually explicit poem inappropriate for either the pen or the ear of the virgin queen.

Almost as if to indicate that he was not arranging his selections haphazardly, the collector placed next a poem that continues this series of increasingly submissive women. In it, a chaste nun falls in love with a falconer and wishes that she would become a falcon so that she could remain with him. The gods smile and decree that it shall be so. And the falconer agrees to perform the transformation. Yet his methods, and the narrator's description, develop sexual overtones, and a series of double entendres eventually makes clear that the metamorphosis under way is that of a maid becoming sexually experienced.

And bothe her armes he bid her clipp for profe of prety thinges Whiche thoughe at firste she nylde to doe yet needes she must haue (winges Her legges lykwyse he layes aparte her feete he gann to frame, Wherat she softlye cride (alas) in faythe you are to blame

4 Bodleian MS Rawl. poet. 85, fol. 4r; Cummings, 'John Finet's Miscellany,' 107-8. In an appendix, I provide the full text of the poem. 
The woman's exclamation, 'in faythe you are to blame,' could have come from the speaker of the previous text (who indeed says, 'nay faythe yow are to blame'). Also like her, the nun objects to her lover's first moves. Although the falconer replies verbally ('Be still sweet gui ${ }^{\mathrm{r}}$ lle and haue no dreade of me your man'), he comes to resemble the silent lover of 'Naye, phewe nay pishe' when he prevails and 'tricks her vp agayne, and agayne $\mathrm{w}^{\text {th }}$ greate delyghte.' 5 The maid finally transforms not so much into a falcon as into a knowing, willing lover.

Within the span of just five leaves, this manuscript verse collector laid out for himself, and for any readers of his miscellany, a remarkable progression of verses on women variously refusing and submitting to men, proceeding from the chaste queen to the nun turned into a sexually active bird. Like virtually all other early modern manuscript verse collectors, this St. John's student produced a unique book of poems. In balancing polite love lyrics with bawdy verse, however, he was also engaging a practice that would become enormously popular over the next several decades, particularly among young men at the universities and Inns of Court. Together these manuscript verse collectors offer a history of early modern English poetry that differs considerably from those recorded in print, whether in their own time or since. For instance, they circulated several examples of the English Petrarchism well known to students of the period; but they gave especial emphasis to its counterdiscourses, to use Heather Dubrow's term. ${ }^{6}$ Indeed, they showed that the literary game of resisting or rejecting the conventions of Petrarchan verse had become much more widespread and spirited than modern readers have realized. While they exhibited a taste for the Petrarchan idealizations of female figures that experts on gender and sexuality have criticized, they also anticipated modern scholars in demystifying such lofty mistresses. Yet they tended to do so by surrounding the Petrarchan figures with representations of women too misogynist or sexually explicit for their contemporaries to print and,

5 Bodleian MS Rawl. poet. 85, fols 4v-5r ('In Libia lande as storyes tell was bredd and borne'); Cummings, 'John Finet's Miscellany,' 112-14. This poem blends the two styles of literature for which Ovid had become famous in late Elizabethan England-metamorphosis narratives and sexually explicit verse-even as it does away with any classicist pretension.

6 Heather Dubrow, Echoes of Desire: English Petrarchism and its Counterdiscourses (Ithaca: Cornell University Press, 1995). 
therefore, too obscure for many modern readers to access. In short, they tended to collect courtly love poems among parodies of courtly love.

By routinely countering or complementing love poetry with erotic or obscene verse, manuscript verse collectors arguably formed an unrecognized poetic genre, which I call anti-courtly love poetry. They organized this genre by methods that distinguish them from other literary agents, and that indeed demonstrate their own equally unnoticed literary agency. While their copies of canonical texts have attracted considerable scholarly attention, verse collectors' broader contributions to literary history have received little. This has remained the case even as early modernists have cultivated interest in an expanding array of literary agents, beyond the authors generally regarded as the preeminent and, in some accounts, only producers of literature. Early twentieth-century bibliographers, working in particular on English Renaissance drama, prioritized the work of printers and publishers. ${ }^{7}$ More recent scholars of such drama have renewed interest in acting companies, while historians of the book have fostered the emergence of the early modern reader. ${ }^{8}$

7 See, for instance, Alfred W. Pollard, Shakespeare Folios and Quartos: A Study in the Bibliography of Shakespeare's Plays, 1594-1685 (London: Methuen, 1909); __, Shakespeare's Fight with the Pirates and the Problems of the Transmission of his Text (London: A. Moring, 1917); W. W. Greg, Dramatic Documents from the Elizabethan Playhouses (Oxford: Clarendon, 1931); __ Bibliography of the English Printed Drama to the Restoration, 4 vols. (London: Bibliographical Society at the University Press, Oxford, 1939-59);

The Shakespeare First Folio, Its Bibliographical and Textual History (Oxford: Clarendon, 1955); F. P. Wilson, 'Shakespeare and the "New Bibliography,"' The Bibliographical Society, 1892-1942: Studies in Retrospect (London: Bibliographical Society, 1954), 76-135.

8 Regarding theatrical companies, see especially Mary Bly, Queer Virgins and Virgin Queans on the Early Modern Stage (Oxford: Oxford University Press, 2000) and Scott McMillin and Sally-Beth MacLean, The Queen's Men and Their Plays (Cambridge: Cambridge University Press, 1998).

For some of the most traceable early modern English readers, see A. H. Tricomi, 'Philip, Earl of Pembroke, and the Analogical Way of Reading Political Tragedy,' JEGP, 85 (1986), 332-45; Lisa Jardine and Anthony Grafton, "Studied for Action": How Gabriel Harvey Read His Livy,' Past and Present, 129 (November 1990), 30-78; Anthony Grafton, " "Discitur ut agatur”: How Gabriel Harvey Read His Livy,' in Stephen A. Barney, ed., Annotation and Its Texts (New York: Oxford University Press, 1991), 108-29; __ _Gabriel Harvey's Marginalia: New Light on the Cultural History of Elizabethan England,' Princeton University Library Chronicle, 52/1 (Autumn 1990), 21-24; William H. Sherman, John Dee: The Politics of Reading and Writing in the English Renaissance (Amherst: University of Massachusetts Press, 1995); James A. Riddell and Stanley Stewart, Jonson's Spenser: Evidence and Historical Criticism (Pittsburgh: Duquesne University Press, 1995); Kevin Sharpe, Reading Revolutions: The Politics of Reading in Early Modern England (New Haven: Yale University Press, 2000). 
For their part, manuscript experts have turned attention to professional and amateur scribes, usually including manuscript verse miscellanies in surveys including wide ranges of other documents. ${ }^{9}$ While these manuscript studies have clearly informed my work, this book proposes a new approach to verse miscellanies, one that investigates the exceptional, and remarkably consequential, activity of manuscript verse collectors.

Their manuscript miscellanies, in other words, distinguish verse collectors from the authors, stationers, and readers who animate most literary histories. For, while many collectors surely also composed, printed, and read verse, they were not necessarily doing any of these things when they copied or bound together poems in manuscript. When they operated as collectors, they did not necessarily transform themselves into authors by rewriting poems; into stationers by prefacing or publishing them; or into the uncommon sort of Renaissance readers who recorded their interpretations of texts. Instead, verse collectors put texts in new contexts, changing their frames of reference and, so, their referential capabilities. They precluded certain interpretations of poems and facilitated others. And they fostered new relationships between verses, associating originally unrelated works and consolidating the genre of anti-courtly love poetry.

Collectors of John Donne's poems played a major role in forming this genre, and so this book devotes considerable attention to their reception of Donne's influential examples of this style of verse. His collectors made Donne the most popular poet in early modern literary manuscripts, by preserving over 5,000 extant copies of his individual works. ${ }^{10}$ Of all

9 Harold Love, Scribal Publication in Seventeenth-Century England (Oxford: Clarendon, 1993), esp. 231-83; Arthur F. Marotti, Manuscript, Print, and the English Renaissance Lyric (Ithaca: Cornell University Press, 1995), esp. 17-25, 30-73; H. R. Woudhuysen, Sir Philip Sidney and the Circulation of Manuscripts, 1558-1640 (Oxford: Clarendon, 1996), esp. 134-73; Peter Beal, In Praise of Scribes: Manuscripts and their Makers in Seventeenth-Century England (Oxford: Clarendon, 1998), esp. 104, 242, 257. Only Mary Hobbs has devoted a book exclusively to early modern manuscript verse miscellanies: Early Seventeenth-Century Verse Miscellany Manuscripts (Aldershot, Hants: Scolar, 1992). In addition to focusing on different authors, poems, and manuscripts than I do here, Hobbs valued miscellanies primarily for the authorial texts that they provide editors, whereas I emphasize the authority of their compilers - that is, the capacity of verse collectors to relate texts to one another and to new contexts without the knowledge or approval of authors.

10 Beal, Index, 1:1:342-564, 566-68; John Donne, The Variorum Edition of the Poetry of John Donne, gen. ed. Gary A. Stringer, vol. 2 (Bloomington: Indiana University Press, 2000), xxxii-xxxvii, xlix. 
Donne's poems, these collectors most often reproduced his anti-courtly love poems such as 'To his Mistress going to bed' and 'The Anagram.'11 Yet they tended to gather these sexually explicit Donne texts among more or less related poems by Christopher Marlowe, Thomas Nashe, Sir John Davies, Francis Beaumont, and a number of anonymous poets, including the unknown author or authors of 'Naye, phewe nay pishe.' In the hands and anthologies of verse collectors, such licentious poems begin to look like a coherent poetic mode-one that Donne had mastered but which other poets had certainly engaged as well. For, by gathering them together, collectors emphasized the fact that each of these poems mocks, opposes, or rejects the Petrarchan conventions of late Elizabethan courtly love poetry.

Following the emergence of courtly love poetry at the late Elizabethan court (signaled in particular by Sir Philip Sidney's Astrophil and Stella and Sir Walter Ralegh's lyrics), poets began to mock the Petrarchan conventions of such courtier verse. William Shakespeare, in surely the most well known example, playfully refused to apply the standard Petrarchan metaphors to the subject of Sonnet 130: 'My mistress' eyes are nothing like the sun.' Likewise in 'The Anagram,' Donne rejected the terms that courtly lovers used in describing their mistresses. Yet, whereas Shakespeare's speaker ultimately honors his unconventionally beautiful mistress as 'rare,' Donne's poem renders its female subject unrealistically disgusting. Donne's Flavia models all of the requisite qualities of a Petrarchan mistress, but attached to the wrong features. Rather than fair skin and red lips, she has yellow cheeks and black teeth, along with small eyes, a big mouth, rough skin, and red hair. She thus features 'an Anagram of a good face.' 12 While Shakespeare playfully resisted courtly love conventions in realistically describing an alluring woman, Donne assaulted them in order to rail against an unbelievably ugly woman. Moreover, while manuscript verse collectors demonstrated little interest in Shakespeare's sonnets, they turned 'The Anagram' into a central example of a genre that they were fashioning themselves.

11 The Donne Variorum editors record 62 copies of 'The Anagram,' 63 of 'The Bracelet,' and 67 of 'To his Mistress going to bed' (Donne Variorum, 2:8, 165, 219).

12 William Shakespeare, The Complete Sonnets and Poems, ed. Colin Burrow (Oxford: Oxford University Press, 2002), 641 ('Sonnet 130,' 1, 13). Donne Variorum, 2:217 ('The Anagram,' 16). 
Manuscript Verse Collectors and the Politics of Anti-Courtly Love Poetry focuses on this genre as the quintessential example of collectors' distinctive ability to cultivate relationships between texts. They demonstrated this capacity by relating anti-courtly love poems not only to one another, but also to literature that originally shared little or nothing in common with these salacious verses. For, while my novel generic term accommodates a number of the collectors' favorite poems, their manuscript miscellanies do indeed feature miscellaneous contents. Among the diverse array of literature in their anthologies, they placed poems on affairs of state, or poetic libels, in particularly compelling relationships with anti-courtly love poems, variously relating the genre to a range of political scandals. ${ }^{13}$ The St. John's compiler, for instance, interrupted his introductory sequence of amatory and erotic verses with a Latin poem celebrating the death of Sir Thomas Gresham, and later included two libels in English: the 'Libell agaynst Bashe,' criticizing the Henrician and Elizabethan victualler of the Navy, and 'The Libell of Oxenforde,' mocking Oxford academics. ${ }^{14}$ Since almost no one printed such slanderous verses at the time, manuscript collectors deserve the credit (or blame) for preserving nearly all of those that survive. ${ }^{15}$ They helped to define the genre of verse libel as well, for instance by exhibiting the aesthetic and historical continuities between poems on the court scandals and royal favorites of early modern England. ${ }^{16}$ Yet, when they juxtaposed libels to anti-courtly love poems, collectors allowed clearly distinct poetic genres to resonate. They simultaneously immersed the poetry of Donne and others in a political culture defined and even

13 On libels, see Andew McRae, Literature, Satire and the Early Stuart State (Cambridge: Cambridge University Press, 2004). On the abundance of sexual and political literature in miscellanies, see Ian Frederick Moulton, Before Pornography: Erotic Writing in Early Modern England (Oxford: Oxford University Press, 2000) and Marotti, Manuscript, Print, and the English Renaissance Lyric, 75-133.

14 Bodleian MS Rawl. poet. 85, fols 2v, 66r-75v; Cummings, 'John Finet's Miscellany,' 92-94, 513-61.

15 For a rare printed libel, see William Goddard, A Neaste of Waspes (Dort: n.p., 1615; STC 11929), sig. F4r. Cited in McRae, Literature, Satire and the Early Stuart State, 28. McRae introduces early Stuart verse libels as an 'unauthorized' genre, which writers engaged under 'an undeniable fear of repression' $(1,7)$.

16 On royal favorites throughout early modern English culture and especially the theater, see Curtis Perry, Literature and Favoritism in Early Modern England (Cambridge: Cambridge University Press, 2006). On early Stuart court scandal, see Alastair Bellany, The Politics of Court Scandal in Early Modern England: News Culture and the Overbury Affair, 1603-1660 (Cambridge: Cambridge University Press, 2002). 
shaped by the topical libels nearby in their miscellanies. Moreover, they introduced a political element to anti-courtly love poetry, and proceeded to modify and tranform the genre's politics as times changed.

Having established such a relationship between libels and anti-courtly love poems in their miscellanies, manuscript verse collectors pose a valuable challenge to dominant distinctions between poetry and politics, literature and history. For, when they copied or bound examples of these two particular genres in their anthologies, collectors did something that literary and political historians have since tended to undo. Editors of Renaissance poetry, for instance, have thoroughly searched these miscellanies, but primarily for more or less authoritative versions of texts attributable to major authors. ${ }^{17}$ The political historians who have turned recently to some of the same manuscript books that interest literary editors have proven to be just as selective, choosing anthologies' most overtly political texts to the exclusion of their more aesthetically complicated ones. ${ }^{18}$ Thus the division of academic labor imposes

17 Editors of John Donne's poetry, in particular, have established an impressive tradition of manuscript scholarship-from the Oxford editors (The Poems of John Donne, ed. Herbert J. C. Grierson, 2 vols. (Oxford: Clarendon, 1912); The Divine Poems, ed. Helen Gardner (Oxford: Clarendon, 1952); The Elegies and The Songs and Sonnets, ed. Helen Gardner (Oxford: Clarendon, 1965); The Satires, Epigrams and Verse Letters, ed. Wesley Milgate (Oxford: Clarendon, 1967); The Epithalamions, Anniversaries and Epicedes, ed. Wesley Milgate (Oxford: Clarendon, 1978)) to John Shawcross and the Donne Variorum committee (The Complete Poetry of John Donne, ed. John T. Shawcross (Garden City NY: Anchor, 1967); Donne Variorum). For a pertinent critique of particularly the Variorum committee's interest in authorial texts, see Marotti, Manuscript, Print, and the English Renaissance Lyric, 147-59.

18 Exemplary historical work on poetic libels includes Bellany, The Politics of Court Scandal; _ 'Libels in Action: Ritual, Subversion and the English Literary Underground, 1603-42,' in Tim Harris, ed., The Politics of the Excluded, 1500-1850 (Basingbroke: Palgrave, 2001), 99-124; __, 'A Poem on the Archbishop's Hearse: Puritanism, Libel, and Sedition after the Hampton Court Conference,' Journal of British Studies, 34/2 (1995), 137-64; __, " "Rayling Rymes and Vaunting Verse": Libellous Politics in Early Stuart England,' in Kevin Sharpe and Peter Lake, eds., Culture and Politics in Early Stuart England (Stanford: Stanford University Press, 1993), 285-310; Thomas Cogswell, 'Underground verse and the transformation of early Stuart political culture,' in Susan D. Amussen and Mark A. Kishlansky, eds., Political Culture and Cultural Politics in Early Modern England: Essays Presented to David Underdown (Manchester: Manchester University Press, 1995), 277-300; Pauline Croft, 'Libels, Popular Literacy and Public Opinion in Early Modern England,' Historical Research, 68/167 (October 1995), 266-85; __, 'The Reputation of Robert Cecil: Libels, Political Opinion and Popular Awareness in the Early Seventeenth Century,' Transactions of the Royal Historical Society, 6th ser., 1 (1991), 43-69; Adam Fox, 'Ballads, Libels and Popular Ridicule in Jacobean England,' Past and Present, 145 (November 1994), 47-83. 
generic distinctions on miscellanies that their compilers evidently viewed differently. Whereas early modern verse collectors gathered diverse texts together, modern disciplinary conventions pry them apart: literary critics get the good poetry, historians get the bad.

This book puts some of the miscellanies' now-canonical and political poems back together, and recognizes relationships between texts and genres that their compilers regularly juxtaposed. Authors first established some of these generic associations. But verse collectors initiated others of their own. For example, those who copied epigrams among short libels on political figures were acknowledging a formal connection that poets had made. ${ }^{19}$ Yet those who gathered anti-courtly love poems among libels were affiliating originally distinct genres in ways that the authors of the older texts involved could not have imagined and, in some cases, would not have appreciated. In this, manuscript verse collectors assumed roles somewhat similar to those of stationers who printed texts without their authors' knowledge or permission. ${ }^{20}$ Manuscript collectors, however, effectively specialized in texts that their contemporaries virtually never printed, like libels, or only rarely published, such as anti-courtly love poems.

In other words, manuscript verse collectors operated somewhat like editors of unprintable poetry anthologies: the successors of Richard Tottel without licenses from the Stationers' Company. Tottel's miscellany, widely considered the first printed anthology of lyric poems in English, differs markedly, for instance, with a nevertheless textually related manuscript verse miscellany such as the Arundel Harington manuscript. The family of the courtier poet Sir John Harington copied

19 On the relationship between the epigram and the libel, see James Doelman, 'Epigrams and Political Satire in Early Stuart England,' Huntington Library Quarterly, 69:1 (March 2006), 31-45.

20 Of particular relevance to the present book, scholars have recently demonstrated how performers, stationers, and readers transformed the politics of relatively old, early modern English literature, especially drama. See Zachary Lesser, Renaissance Drama and the Politics of Publication (Cambridge: Cambridge University Press, 2004); Marta Straznicky, Privacy, Playreading, and Women's Closet Drama, 1550-1700 (Cambridge: Cambridge University Press, 2004); __ _ ed., The Book of the Play: Playwrights, Stationers, and Readers in Early Modern England (Amherst: University of Massachusetts Press, 2006); Paul Whitfield White and Suzanne R. Westfall, eds., Shakespeare and Theatrical Patronage in Early Modern England (Cambridge: Cambridge University Press, 2002); McMillin and MacLean, The Queen's Men and their Plays. 
into this manuscript miscellany many of the same poems that Tottel printed, but alongside others that he could not, or would not, publish. Scholars have suggested that Tottel, and whoever else contributed to the compilation and organization of the volume, subdued its political connotations, deemphasizing the revolutionary associations of Sir Thomas Wyatt's family name by printing the poet's verse relatively late in the first edition; and deleting from the second edition Nicholas Grimald's verses honoring the protestant predecessors of the Catholic Queen Mary I. ${ }^{21}$ By contrast, the Haringtons had no reason to depoliticize their manuscript miscellany. In addition to many of Tottel's texts they transcribed the libels on Edward Bashe and Oxford academics that the St. John's student also collected. ${ }^{22}$ This book investigates the editorial decisions that manuscript verse collectors such as the Haringtons made outside of the regime of prepublication licensing.

In the editorial decisions most relevant to this study, manuscript collectors politicized and recontextualized anti-courtly love poetry with topical libels. Yet, to be sure, they recontextualized other texts as well, even libels themselves. As others have shown, the collectors of the poetic libel known as 'The Parliament Fart' developed and ultimately reversed its political associations over the course of its circulation in the first half of the seventeenth century. The poem originally celebrated a timely fart by a member of James VI and I's first English parliament, Henry Ludlow, immediately following the reading of a message from the House of Lords regarding the naturalization of the Scots, a central issue in James' design to unite Scotland and England. Thus, in its earliest contexts, the libel enacted a gesture of defiance toward the Lords and possibly even the crown on behalf of the Commons and, most likely, certain MPs who also belonged to Donne's coterie: Sir John Hoskyns, Christopher Brooke, Richard Martin, and Edward Jones. Yet few collectors of 'The Parliament Fart' reproduced the poem without modifying, amending, or

21 Songes and Sonettes (London: Apud Richardum Tottel, 1557; STC 13861); Songes and Sonettes (London: Apud Richardum Tottel, 1557; STC 13862); Hyder E. Rollins, ed., Tottel's Miscellany (Cambridge: Harvard University Press, 1928); Paul A. Marquis, 'Politics and print: The curious revisions to Tottel's Songes and Sonettes,' Studies in Philology, 97/2 (Spring 2000), 145-64.

22 Arundel Castle (The Duke of Norfolk), Arundel Harington MS, fols 136r-39r; Ruth Hughey, ed., The Arundel Harington Manuscript of Tudor Poetry, 2 vols. (Columbus: Ohio State University Press, 1960), 1:223-33, 2:276-301. 
recontextualizing it. Indeed, in the middle of the seventeenth century, its royalist collectors ironically used this originally Commons libel to signal their distrust of parliament altogether. ${ }^{23}$ They did so, in no small part, by collecting 'The Parliament Fart' among explicitly royalist texts.

Verse collectors also repoliticized several poems by another of Donne's close friends, Sir Henry Wotton. Over time they applied Wotton's libel on the fall of James' royal favorite Sir Robert Carr, earl of Somerset, to other political figures: Sir Walter Ralegh, Sir Francis Bacon, George Villiers duke of Buckingham, and 'Secretarye Dauison,' presumably the Elizabethan secretary of state William Davison. ${ }^{24}$ Likewise, they reassigned Wotton's poem on James' daughter, Elizabeth, to other royal women. Some copyists redirected the poem to the princess' mother, Queen Anne. ${ }^{25}$ Others provocatively reapplied Wotton's high praise of Elizabeth to the Spanish Infanta, Donna Maria Anna, whom James proposed to marry to Prince Charles. ${ }^{26}$ In this remarkable example of appropriation, collectors completely overturned the poem's religious and political affiliations. For whereas Princess Elizabeth and her husband, the Elector Palatine, embodied English protestants' hope for an international alliance against Catholicism, the Spanish Infanta

23 Michelle O'Callaghan, 'Performing Politics: The Circulation of the "Parliament Fart," ' Huntington Library Quarterly, 69/1 (March 2006), 121-38. Marotti, Manuscript, Print, and the English Renaissance Lyric, 113-15.

24 Ted-Larry Pebworth, 'Sir Henry Wotton's "Dazel'd Thus, with Height of Place" and the Appropriation of Political Poetry in the Earlier Seventeenth Century,' Papers of the Bibliographical Society of America, 71 (1977), 151-69. The Poems of Sir Walter Ralegh: A Historical Edition, ed. Michael Rudick (Tempe: Arizona Center for Medieval and Renaissance Studies, 1999), lxvii-lxviii, 122, 223-24. Rudick notes that British Library MS Lansdowne 777, fols 63r-66r, features 'a string of poems with Ralegh connections,' including Wotton's poem attributed correctly and headed 'To a favorite': 'The context there appears to be poems applied to Ralegh.' The Yorkshire antiquary John Hopkinson headed the poem 'On Secretarye Dauison fall' in his late-seventeenth-century miscellany: West Yorkshire Archive Service, Bradford MS 32D86/17, fol. 123v. See Simon Adams, 'Davison, William (d. 1608),' $O D N B$.

25 British Library MS Add. 30982, fol. 145v rev.; Folger MSS V.a.170, pp. 43-44; V.a.245, fol. $42 \mathrm{v}$.

26 Bodleian MS Malone 19, pp. 37-38; Folger MS V.a.162, fol. 79r-v; Houghton MS Eng. 686, fols 9v-10r. C. F. Main first pointed out two of these appropriations in the concluding footnote to his "Wotton's "The Character of a Happy Life,", The Library: Transactions of the Bibliographical Society, 5th ser., 10/4 (1955), 270-74. For the fullest discussion on the development of the text of the poem throughout its transmission, see J. B. Leishman, "YYou Meaner Beauties of the Night": A Study in Transmission and Transmogrification,' The Library, 4th ser., 26/2-3 (September, December 1945), 99-121. 
represented James' apparent threat to dissolve any such alliance by marrying the Prince of Wales to a Spanish Catholic. Wotton collectors appropriated his poems both by providing them with new headings and by surrounding them with texts on later political events and figures.

In the middle of the seventeenth century, Robert Overton, an officer in the Parliamentary army, appropriated other manuscript verses. He dedicated a compilation of excerpts of love poems by Donne and Katherine Philips to his deceased wife, Ann. As a pious Independent and supporter of the Parliamentary cause, Overton makes for a surprising reader of the avowed royalist Philips. Moreover, as a mourning husband who turned the love poems of Donne and Philips into a memorial befitting a devout puritan woman, Overton demonstrates how completely manuscript verse collectors could assimilate texts to their own contexts. ${ }^{27}$ Yet relatively few collectors appropriated literature in the dramatic fashion that Overton did. Many more collectors recontextualized the literature in their miscellanies simply by surrounding less topical texts with more topical ones. In addition to libels, their miscellanies typically feature several occasional genres that regularly identify individuals or events and, so, tend to relate nearby texts to new contexts: verse letters; prose epistles; funeral elegies; laudatory and mock epitaphs; verses on figures and events at the universities and Inns of Court; and reports of legal trials. On the other hand, early modern verse collectors also filled their miscellanies with genres that, like anti-courtly love poems, regularly leave their original contexts rather unclear and, so, remain particularly open to recontextualization: epigrams that are too reserved to count as libels; love lyrics that are more polite than anticourtly love poems; devotional verse and prose; texts on religious difference, most of them directed against unspecified Catholics or puritans; 'characters' that represent a cross-section of early modern English society in caricature; verses on the querrelle des femmes, or battle over women, including a number of poems on choosing a wife; and many others. Verse collectors tended to recontextualize texts such as these with topical or political literature, if only by gathering them together.

By attending to the effects of such collection practices, this book then presumes that poetic meaning need not be limited to what a poet puts

27 David Norbrook, " "This blushing tribute of a borrowed muse”: Robert Overton and his overturning of the poetic canon,' English Manuscript Studies, 1100-1700, 4 (1993), 220-66; Princeton MS C0199 (no. 812). 
into a poem, what a reader gets out of it, or what a critic finds in it alone. A poem's full significance, rather, may extend beyond its text to the affiliations and resonances that it develops among other texts and in its various contexts, no matter how local or even physical. Both its historical contexts and its manuscript contexts, in other words, influence what a poem comes to signify, or at least what it comes to suggest. This book thus takes contextual reading to a certain extreme, not only because it proceeds to contexts well beyond those of composition and initial reception but also because it reasons that, if a poem's context determines its meaning, then variations in even its physical, manuscript context may change the poem's meaning.

In attributing meaning to the activity of verse collectors, though, my argument does not require presuming that they intended to generate all of these associations and connotations. Given the thorough criticism of authorial intention in literary studies, I would not reduce the significance of collectors' literary contributions to their intentions any more than I would that of authors'. Some anthologists may have intended to do no more than collect poems that they happened to like, or happened to encounter. Yet even such casual collectors recorded invaluable information regarding their access to texts; their tastes; their working definitions of literary genres, or lack thereof; and their perspectives on recent politics. Without necessarily realizing the ramifications of their actions, many of these anthologists effectively formed, mixed, and politicized certain literary genres. On the other hand, collectors such as those introduced in the following chapter, who attempted to reconstruct the politics of anti-courtly love poetry, inadvertently introduced factual errors and other incongruities to their accounts of literary and political history. Manuscript Verse Collectors and the Politics of Anti-Courtly Love Poetry focuses on the ironies, as well as the continuities, of the genre's shifting political affiliations in the changing political contexts of early seventeenth-century England.

By attending to the politics of both libels and anti-courtly love poems, this study also engages the different kinds of politics prioritized in the disciplines of English and history. While historians have assessed the politics of libels, and literary critics have discerned those of Donne's Ovidian elegies, they have not always shared the same conception of politics. The post-revisionist historians who have analyzed libels have expanded their discipline's 'definition of the political' to include the 
construction and perception of court scandals. ${ }^{28}$ Literary critics, on the other hand, have opened up their working notion of politics even more, by positing the politics of a range of cultural phenomena that have little or nothing to do with the state- such as, in the case of Donne's elegies, representations of power relations between men and women. Manuscript verse collectors require an interdisciplinary approach that engages both state and cultural politics and considers their relationship to one another. For, when they gathered together libels and anti-courtly love poems, they likewise forced these two kinds of politics together. One could say that the authors of libels did as much on their own, given how many of them attacked court figures specifically by mocking their gender, sexuality, religion, class origins, or nationality. Yet, by surrounding such libels with Donne's and others' anti-courtly love poems, collectors effectively challenged their readers to recognize and negotiate the relationship between these two conceptions of politics. This book enthusiastically takes up the challenge.

The theoretical developments outlined here proceed directly from the material practices of manuscript verse collectors. Such ambitious claims on behalf of collectors require a careful consideration of how they made their manuscripts, and of who most likely selected and arranged the texts within these rare books. The next section of the chapter turns to such a consideration by briefly surveying some of the ways in which they constructed and compiled their miscellanies, and by endeavoring to assign agency as precisely as possible.

\section{THE MEANS OF REPRODUCTION AND RECONTEXTUALIZATION}

The St. John's student with which this study began exhibited one ordinary method of compiling a manuscript verse miscellany. He copied poems into a bound, blank book. Before he starting writing in it, the book had been fully constructed, the margins ruled, and the leaves foliated. He could have purchased such a blank book ready-made but, having purchased paper and a few other supplies instead, he also could have made his book by himself, or with the help of others: perhaps a 
professional bookbinder, or a friend or family member. Whoever contributed to the production of the codex completed the physical book before the compiler filled it in. Whether professional or volunteer, the labor of book construction was complete before the amateur work of transcription began. ${ }^{29}$

His miscellany thus represents one of a variety of ways that people produced manuscript verse miscellanies in early modern England. Others made anthologies in a reverse fashion, by simply binding together verses (often along with other types of writing) that were already written on loose papers; on individual sheets folded once, twice, or three times (resulting in a bifolium, quarto, or octavo, respectively); or in larger gatherings or booklets made of several sheets or half-sheets of paper. Verse regularly circulated in small booklets like these. The St. John's student probably transcribed texts from several such documents into his blank book. Verse collectors could also copy their contents onto other loose leaves or into other small gatherings. Or they could simply keep the little manuscripts that they acquired. Rather few small, individual poetry manuscripts survive unbound. Most of these booklets have been bound together with other documents (if not by their original owners then by a descendant, a rare book collector, or a librarian). Binding together several manuscripts in this fashion results in a composite manuscript. Composite manuscripts commonly feature a wide range of papers and scripts, and so visibly contrast with a book that, like the manuscript of the St. John's student, was constructed all at once and filled in by one hand. The compiler of the St. John's miscellany acted as both its editor and its scribe, but may not have engaged in the construction of his book. A verse collector responsible for a composite manuscript, on the other hand, could have contributed to certain stages of his miscellany's physical production (when he collected his papers, and especially if he ordered them and arranged for them to be bound); but he may have done none of the writing therein.

After collecting or copying manuscripts themselves, people could also have their papers professionally copied. Successful men customarily did this when they prepared their wills. Sir John Finet did so long after he attended St. John's, Cambridge and either befriended the compiler of the miscellany considered at the start of this chapter or compiled it 
himself, as the manuscript's editor, Laurence Cummings, has suggested. ${ }^{30} \mathrm{~A}$ scribe likewise copied the papers of the judge Sir Christopher Yelverton near the time of his death in 1612, resulting in a thick quarto of verse and mostly political prose. ${ }^{31}$ Although Yelverton collected texts composed at various dates throughout his long Elizabethan career, a professional transcribed them all at once, and in no apparent order. The scribe who did so might have served as a personal secretary to Yelverton. Or a clerk or a full-fledged scrivener could have copied a judge's papers, as each worked primarily on legal documents. ${ }^{32}$ Yet judges and lawyers surely could look beyond the legal community for scribes, just as scribes could work both within and without the Inns of Court. Indeed, sometime after 1634, a scribe who regularly worked for the theater produced a verse miscellany that was owned by the family of the lawyer Chaloner Chute. ${ }^{33}$ Chute may have collected the texts for his miscellany and contracted the playhouse scribe to make a fair copy of them. Yet it is also possible (although impossible to prove) that this scribe provided or even chose texts for his client.

30 Sir John Finet, Ceremonies of Charles I: The Note Books of John Finet, 1628-1641, ed. A. J. Loomie (New York: Fordham University Press, 1987); Roderick Clayton, 'Finet, Sir John (1570/71-1641),' ODNB; Cummings, 'John Finet's Miscellany,' 27-32. Randall Anderson doubts Cummings' identification of Finet as the copyist of the manuscript in " "The Merit of a Manuscript Poem": The Case for Bodleian MS Rawlinson Poet. 85,' in Arthur F. Marotti and Michael D. Bristol, eds., Print, Manuscript and Performance: The Changing Relations of Media in Early Modern England (Columbus: Ohio State University Press, 2000), 127-71, esp. 168-69 n.77.

31 All Souls, Oxford MS 155. I discuss this manuscript at greater length in " "From a seruant of Diana" to the Libellers of Robert Cecil: the Transmission of Songs Written for Queen Elizabeth I,' in Peter Beal and Grace Ioppolo, eds., Elizabeth I and the Culture of Writing (London: British Library, 2006), 115-31.

32 A scribe generally apprenticed under a scrivener before becoming a clerk. Love, Scribal Publication, 92-101, esp. 94.

33 British Library MS Add. 33998. The other known manuscripts in the hand of this scribe are each theatrical: British Library MS Egerton 1994, fols 30-51 (Thomas Heywood, Dick of Devonshire, post-1626); Folger, Printed Books, STC 17876 (MS addition to Thomas Dekker (or Thomas Middleton?), Blurt, Master-Constable (London, 1602)); Worcester College, Oxford, Printed books, Plays.2.5 (George Chapman, May-Day, 1611). I thank Peter Beal for this information. See his Index 1:2, HyT (Thomas Heywood) 5; MiT (Thomas Middleton) 6. For a summary of the evidence, see Beal, 'The Folger Manuscript Collection: A Personal View,' in Heather Wolfe, ed., 'The Pen's Excellencie: Treasures from the Manuscript Collection of the Folger Shakespeare Library (Washington DC: Folger, 2002), 16-17. Chute, incidentally, would eventually succeed Yelverton as speaker of the House of Commons, in Richard Cromwell's parliament of 1659. Christopher W. Brooks, 'Chute, Chaloner (c.1595-1659),' ODNB. 
Regardless of who selected the texts in his miscellany, the presentable hand of the theatrical scribe suggests that Chute purchased the manuscript, possibly as a finished product. Chute's manuscript thus qualifies as one of rather few evidently professional early seventeenth-century verse miscellanies. The so-called Feathery Scribe also produced a verse miscellany, which is unique among the more than 100 manuscripts that Peter Beal has attributed to this law clerk and professional scribe, most of which consist of political, historical, legal, or religious prose. ${ }^{34}$ Because it presents such an anomaly in the scribe's extant body of work, and since the miscellany shows 'Feathery in full showcase mode,' Beal convincingly suggests that a client commissioned the anthology. Again, Feathery may have offered texts or editorial suggestions to his client. Yet the customer surely helped to determine the content of his miscellany.

If scribes received commissions for complete manuscript verse miscellanies such as these, one wonders whether they also produced finished anthologies speculatively, for expected yet uncommitted customers, in more or less the same way that stationers printed books. Scribes evidently did this in the late seventeenth century: scholars of this later period have attributed several anthologies of political and erotic poems to networks of professional scribes called scriptoria (regardless of whether the scribes worked at a communal space or in their separate homes). ${ }^{35}$ Acknowledging that few 'entrepreneurially published' miscellanies predate 1680, Harold Love has recognized that the professional miscellanies surviving from the late seventeenth century nevertheless resemble their Elizabethan and early Stuart predecessors. ${ }^{36}$ Could a professional scribe have made one of these earlier miscellanies without knowing who would buy it? This is possible, but far from certain. Several late sixteenth and early seventeenth-century miscellanies feature signs of professionally trained labor: virtuosic penmanship; uniform gatherings made from a single stock of paper; attractive contemporary bindings. Yet an early modern Englishman surely could have employed a 'professional hand' even when he did not expect payment for the manuscript at hand. Amateurs, like professionals, would have had occasion and incentive to work with a single stock of paper. And, again, bookbinders bound blank books, loose papers, and collections

34 Bodleian MS Rawl. Poet. 31. Beal, In Praise of Scribes, 72, 104, 257.

35 Love, Scribal Publication, 232, 124-26.

36 Love, Scribal Publication, 75, 79. 
of small manuscripts, so a professional binding by no means indicates that a finished miscellany was produced for a speculative market.

Furthermore, while professional scribes have left little evidence that they sold manuscript miscellanies like printed books in the early seventeenth century, an extensive record of amateur involvement remains in such volumes. Sloppy, and thus clearly unprofessional, writing abounds in many of these books. Irregular gatherings, each featuring a different number of leaves, can be found even in manuscripts made primarily with a single stock of paper. In the absence of any clear indication that professional scribes produced verse miscellanies for a speculative market before the end of the seventeenth century, such obvious signs of unpaid labor indicate that the editorial work of selecting and arranging their texts regularly fell to amateurs: to the people who enjoyed, or at least prized and preserved, early modern English poetry. These verse collectors thus were acting more like consumers than businessmen when they made their anthologies. Indeed, they would have been consumers at virtually every other stage of their books' production: when they purchased the raw materials (such as paper, or a blank book); if they paid for any small, unbound manuscripts; if they contracted a scribe to make a fair copy; and if they had a bookbinder sew everything together. While amateur verse collectors then did not produce every aspect of all early modern manuscript miscellanies, the editorial stage of obtaining, selecting, and arranging texts nevertheless commonly involved the work of individuals who could expect no payment for their labor: the readers, consumers, and users of literature.

Like the St. John's compiler, many of these relatively private collectors circulated verse at one of the universities. After university, many of them proceeded to another center for verse collection, the Inns of Court, where Chute and Yelverton doubtless acquired some of their texts. Verse collectors also operated at the royal court and certain family households, especially those privileged with a secretary, a tutor, or literary patronage clients. ${ }^{37}$ Perhaps ironically, professional scribes may have participated in the editorial stages of making a poetry anthology at such domestic sites more often than anywhere else. Perhaps while employed as a secretary to Francis Fane, first earl of Westmoreland, Rowland Woodward

37 Woudhuysen, Sir Philip Sidney, 163-73. Marotti, Manuscript, Print, and the English Renaissance Lyric, 30-48. 
transcribed one of the most authoritative collections of the poems of his friend, John Donne. ${ }^{38}$ John Rolleston, the personal secretary of William Cavendish, earl (and later duke) of Newcastle, produced one of the most visually striking miscellanies of the early seventeenth century. ${ }^{39}$ Hilton Kelliher has shown that, in addition to managing the earl's correspondence, Rolleston amended and copied Newcastle's own literary compositions, and transcribed the whole of the Cavendish family verse miscellany in a beguiling range of distinct scripts. ${ }^{40}$ Newcastle may have taken the dominant role in acquiring and selecting texts for this manuscript, given his literary interests and impressive patronage network (which included Ben Jonson and the poet and doctor Richard Andrews, each of whom, along with Donne, composed great numbers of the poems in the Newcastle manuscript). For, after all, even if such editorial duties fell to Rolleston, the secretary worked for the earl and would have tried to please him. Yet a personal secretary like Rolleston played a much more significant part in his master's affairs than did a clerk or scrivener in those of his clients. In a contemporary formulation, a secretary was 'in one degree in place of a servant... in another degree in place of a friend.' Unlike a mere hired hand, a secretary needed to be capable of using 'the Pen, the Wit and Inuention together.' ${ }^{41}$ It is difficult to tell, but tempting to wonder, to what extent Rolleston applied his wit and invention, in addition to his pen, to the impressive Newcastle manuscript.

Other early modern households left verse collection to other servants. Henry Stanford, for example, compiled an important late Elizabethan miscellany while he served as a tutor at a couple of aristocratic houses. ${ }^{42}$ His anthology features court poems among verse by himself and his students. Although Stanford was acting in a professional capacity when he had his students compose verse, he seems to have written and collected poems in his leisure. In general, families that produced miscellanies, like the Haringtons, must have done so in their leisure hours as

38 New York Public Library, Berg Collection, Westmoreland MS.

39 British Library MS Harley 4955.

40 Hilton Kelliher, 'Donne, Jonson, Richard Andrews and The Newcastle Manuscript,' English Manuscript Studies, 1100-1700, 4 (1993), 134-73.

41 Love, Scribal Publication, 97. Quotes Angel Day, The English secretary, ed. Robert O. Evans (Gainesville FL: Scholars', 1967), $106^{\mathrm{b}}, 129^{\mathrm{b}}$.

42 Cambridge University Library MS Dd. 5.75; Steven W. May, Henry Stanford's Anthology: An Edition of Cambridge University Library Manuscript Dd.5.75 (New York: Garland, 1988). 
well. Probably throughout the 1620 s and '30s, the Skipwith family of Cotes, Leicestershire put together a composite manuscript, beginning with poems by Donne that they could have acquired from Donne's friend, and their own relative by marriage, Sir Henry Goodyer. ${ }^{43}$ To these quires they added other distinct gatherings in several different hands with poems by Donne, Goodyer, Beaumont, Wotton, Sir Nicholas Hare, and a few members of their own family. Finally, a possibly seventeenth-century hand filled in the manuscript's blank spaces with additional verse. Although they made their miscellany in such a piecemeal fashion, the Skipwiths generally collected poems that were related to one another by theme or social context. In a family, as in a coterie of like-minded students or friends, a collective effort of anthologizing could thus maintain some consistency.

On the other hand, the Skipwiths' method of verse collection did lead to a few interesting juxtapositions, especially when they grouped topical verses with well-known poems by Donne and Beaumont. In Chapters 3 and 4, I return to the Skipwith manuscript to demonstrate the difference that such recontextualizations made to the political and religious associations of Donne's and Beaumont's anti-courtly love poems. From the current section's perspective on the means of producing miscellanies, though, it is worth acknowledging that, given how verse collectors made these books, the fact that they recontextualized literature should not surprise modern readers. When people collected poems from different sources, added to anthologies over a period of time, or bound different manuscripts together, recontextualizations necessarily occurred. Yet this material observation hardly accounts for the content and historical significance of particular recontextualizations, which offer plenty of surprises to students and scholars of early modern English literature, and to which the remainder of this book turns.

\section{THE FORMATION AND POLITICIZATION OF A GENRE}

When he went to St. John's in the late sixteenth century, the manuscript verse collector introduced at the beginning of this study arrived at a

43 British Library MS Add. 25707. 
particularly good place to find erotic poetry. Several of the texts that he transcribed indicate that he belonged to a social circle of St. John's students who evidently appreciated such verse, including John Finet, James Reshoulde, and Robert Mills. Indeed, one of these young men probably compiled the manuscript. Finet would go on to gain a reputation at the court of King James for composing bawdy songs to the delight (and once, apparently, to the extreme displeasure) of the king. ${ }^{44}$ Reshoulde demonstrated his interest in such literature when he wrote a 'ribald ballad.' 45 And Robert Mills translated Ovid's Amores I.5, as did another contemporary Cambridge student, Christopher Marlowe, who Englished all of Ovid's elegies. ${ }^{46}$ In addition, Mills collaborated with yet another St. John's student, Thomas Nashe, on an entertainment that seems to have resulted in Mills being 'expelled the Colledge' and Nashe departing for London without his master's degree. ${ }^{47}$ Whoever compiled this miscellany collected poems among several authors and readers of Ovidian and otherwise sexually explicit literature in Cambridge.

Indeed, in the days of Marlowe and Nashe, Cambridge must have offered the best place in England to find anti-courtly love poems. ${ }^{48} \mathrm{Each}$

44 Finet, Ceremonies of Charles I. In a libel on James I's court ('Listen jolly gentlemen'), Finet (referred to as 'Jacke Finnett') is numbered among the king's 'merry boys ... with masks and toys.' Bodleian MS Malone 23, pp. 19-22, as transcribed in Alastair Bellany and Andrew McRae, ed., 'Early Stuart Libels: An edition of poetry from manuscript sources,' Early Modern Literary Studies, Text Series 1 (2005), L5. http://purl.oclc.org/ emls/texts/libels/ accessed 22 June 2005. The editors note that, according to Anthony Weldon, Finet composed the 'bawdy songs' that Sir Edward Zouche, Knight Marshall, would perform for the king, and that John Chamberlain reported the performance in which Finet went too far. In January 1618, at James' palace at Theobald's, he sang 'a certain song... of such scurrilous and base stuffe that it put the King out of his good humor, and all the rest that heard it.' Anthony Weldon, The Court and Character of King James (London: R.I. and are to be sold by John Wright, 1650; Wing W1273), 91-92; John Chamberlain, The Letters of John Chamberlain, ed. Norman Egbert McClure, vol. 2 (Philadelphia: American Philosophical Society, 1939), 131. See also Clayton, 'Finet.'

45 Cummings, 'John Finet's Miscellany,' 33, 497-500; Bodleian MS Rawl. poet. 85, fol. $64 \mathrm{r}-65 \mathrm{r}$.

46 Bodleian MS Rawl. poet. 85, fol. 81r-v; Cummings, 'John Finet's Miscellany,' 585-89. See Woudhuysen, Sir Philip Sidney, 259-60; Hilton Kelliher, 'Unrecorded Extracts from Shakespeare, Sidney and Dyer,' English Manuscript Studies, 2 (1990), $163-87$.

47 Gabriel Harvey, The Trimming of Thomas Nashe Gentleman (London: for Philip Scarlet, 1597; STC 12906), sig. G3r-v. Cummings, 'John Finet's Miscellany,' 575, also 34-39, 570-76.

48 Consider John Carey, 'The Ovidian Love Elegy in England,' (DPhil diss., Oxford University, 1960), 154-55. 
of the earliest examples of the genre that recur in seventeenth-century manuscript verse miscellanies has links to the university: Marlowe's translations of Ovid's elegies; Nashe's 'The choise of valentines'; and the anonymous 'Naye, phewe nay pishe,' which at least circulated at St. John's. The vogue for erotic verse likely spread from Cambridge via the influence of Marlowe. Like so many early modern English writers, most of the other prolific anti-courtly love poets drew on Marlovian models. Shakespeare, like many writers connected to the Inns of Court, wrote epyllia based on Ovid's Metamorphosis that looked to Marlowe's Hero and Leander. Sir John Davies' most popular anticourtly love poems first appeared in print with Marlowe's translations of Ovid's elegies. ${ }^{49}$ And Donne, who would master the anti-courtly love style among several other poetic genres, most clearly indicated his engagement with Marlowe in 'The Bait,' which takes its first line from Marlowe: 'Come live with mee, and be my love.'50 Given Marlowe's fame and his reputation as a translator of Ovid, Donne must have written his own Ovidian love elegies and other anti-courtly love poems with Marlowe in mind as well.

Another late sixteenth-century verse collector gave Cambridge University wits a prominent place in his account of English poetry, and emphasized their anti-courtly love poetry in particular. He included in his miscellany, now at the Rosenbach Library, Marlowe's 'If thou wilt liue and be my loue' with another 'answeare' to his famous lyric, this one beginning in a woman's voice, 'If that the world \& loue weare young. ${ }^{51}$ Moreover, he collected several anti-courtly love poems from Cambridge: the only other Elizabethan copy of 'Nay pish: nay pue'; a short version of Nashe's 'The choise of valentines' that ends before the prostitute in other copies famously resorts to a dildo; and Marlowe's

49 Sir John Davies and Christopher Marlowe, Epigrammes and Elegies. By I.D. and C. M. (Middleborough[?]: n.p., n.d.[1599?]; STC 6350).

50 Christopher Marlowe, The Complete Works of Christopher Marlowe, ed. Fredson Bowers, 2nd edn, vol. 2 (Cambridge: Cambridge University Press, 1973, 1981), 536-37.

51 Rosenbach MS 1083/15, pp. 57 ('If thou wilt liue and be my loue'), 57-58 ('Her answeare.//If that the world \& loue weare young'); James L. Sanderson, 'An Edition of an Early Seventeenth-Century Manuscript Collection of Poems (Rosenbach MS. 186)' (PhD diss., University of Pennsylvania, 1960), lxix-lxxxi, 288-301. I thank Greg Giuliano for providing me with timely photographs of this manuscript, in addition to his hospitality at the Rosenbach. 
translation of Ovid's sexual encounter with Corinna. ${ }^{52}$ Rather than balance these erotic verses with courtly lyrics, as did the collector from St. John's, the initial compiler of this Rosenbach manuscript accentuated their style with similarly direct epigrams and crude sexual verse. For instance, he placed first in his miscellany a poem full of sexual innuendo on a pair of lovers playing card games named 'maw' and 'Ruff.' This introductory poem thus resonates with the collector's copy of 'Nay pish: nay pue' on the very next leaf, especially where its speaker complains 'you marr my ruffe' and finally invites her lover to 'come goe to cardes.' 53 The collector fit in between these texts a poem aligning women with roses and men with thorns, or 'prickles,' and a verse graphically detailing the physical characteristics 'required' for a woman to be considered 'faire.' 54 While the St. John's compiler distinguished the female monologue from court poetry, this anthologist featured his copy of 'Nay pish: nay pue' in a block of similarly unpretentious erotica.

Likewise, this manuscript verse collector surrounded Nashe's account of a trip to a brothel with appropriate companion pieces. He introduced it with a short verse 'Of Brothell houses.' Then, after Nashe's prostitute made his speaker's 'Priapus as stiffe as steele,' he copied an epigram that likens the 'pricke' of one Grunnus to 'Paulsteeple.' $55 \mathrm{He}$ similarly followed Marlowe's translation of Ovid with short verses that emphasize its speaker's single-minded focus on sex. Marlowe's Ovidian persona does nothing more to woo Corinna than lie on a bed and tear off her gown as she passes. Immediately below this scene in the Rosenbach manuscript, its compiler inscribed a three-line apostrophe beckoning 'noble Tarse loues slaue' to rise out of his 'codpiece' and 'dig thy selfe a

52 Rosenbach MS 1083/15, pp. 3 ('Nay pish: nay pue: nay faith [ ] will you fie'), 18-22 ('ffaire was the morne \& brightsome was the day'), 43 ('In som[m]ers heat at midtyme of the day'); Sanderson, 'An Edition of an Early Seventeenth-Century Manuscript Collection of Poems,' 9-12, 91-100, 209-12. Sir John Davies, The Poems of Sir John Davies, ed. Robert Krueger (Oxford: Clarendon, 1975), 443-44.

53 Rosenbach MS 1083/15, pp. 1 ('On Holy euen when w[inter]s nightes waxe longe'), 3; Sanderson, 'An Edition of an Early Seventeenth-Century Manuscript Collection of Poems,' 1-3, 9-12.

54 Rosenbach MS 1083/15, p. 2 ('Your Rose [is sw] eet \& woma[n]like in smell'; 'In choice of faire are thirty thinges required'); Sanderson, 'An Edition of an Early Seventeenth-Century Manuscript Collection of Poems,' 5-6.

55 Rosenbach MS 1083/15, pp. 21, 22 ('In Grunnu[m]//Grunnus his pricke is like Paulsteeple turnd'); Sanderson, 'An Edition of an Early Seventeenth-Century Manuscript Collection of Poems,' 89-101. 
graue betweene my $\mathrm{m}^{\text {es }}$ thyghes. ${ }^{56} \mathrm{On}$ the verso of the leaf that features this crude piece, he offered yet another especially direct lover: a 'cuntry swadd,' whose unadorned method of courting contrasts with the behavior of 'a courtier.' In the brief poem by Sir John Davies, both characters attempt to woo the same 'Lady Faire.'

The Courtier first came lepping in

\& tooke the Lady by the chin the cuntry swadd as he was blunt came tooke the lady by the elbow.

I $\mathrm{D}^{57}$

Once the reader instinctively replaces the last word with one that rhymes, the leaping courtier appears ridiculously indirect as compared to the carnally minded lovers whom this manuscript verse collector, like so many others, showcased in his miscellany.

With these poems, the compiler of the Rosenbach manuscript organized a fine exhibition of late Elizabethan anti-courtly love poetry. He brought together some of the most canonical, most popular, and most obscure examples of the genre available to manuscript verse collectors in the late sixteenth century, in particular at the Inns of Court. The unknown individual responsible for beginning this miscellany must have had at least social, if not official, connections to the Middle Temple. For, in addition to a fine collection of the poetry of the Middle Templar Sir John Davies, he acquired the extremely rare epigrams of Benjamin Rudyard, who belonged to the same Inn of Court. ${ }^{58}$

In addition to helping to locate the initial compiler of the Rosenbach miscellany, the Davies poems that he collected demonstrate how he began to politicize his collection of anti-courtly love poetry. With the

56 Rosenbach MS 1083/15, p. 43 ('O noble Tarse loues slaue out of my codpeece rise'); Sanderson, 'An Edition of an Early Seventeenth-Century Manuscript Collection of Poems,' 213.

57 Rosenbach MS 1083/15, p. 44 ('A Lady faire two suiters had'); Sanderson, 'An Edition of an Early Seventeenth-Century Manuscript Collection of Poems,' 215. See Poems of Sir John Davies, 181, 402.

58 Rosenbach MS 1083/15, pp. 48-56; Sanderson, 'An Edition of an Early Seventeenth-Century Manuscript Collection of Poems,' 237-87; Poems of Sir John Davies, 443-44. Incidentally, Sir Benjamin Rudyard would also be one of the executors of John Finet's will, along with Sir Thomas Roe, both poets and members of Donne's coterie. Clayton, 'Finet.' 
help of a collaborator, he added to his miscellany several late sixteenthcentury verse libels, most notably some of Davies' satirical poems on the second marriages of both Richard Fletcher, Bishop of London, and Edward Coke, Attorney General.59 Moreover, the sixteenth-century compilers of the Rosenbach miscellany interspersed among Davies' libels crude verses on genitals, which extend the collectors' presentation of erotic poetry into the midst of such slanderous satirical verse. In fact, they effectively introduced the libels' critical accounts of the Fletcher marriage with an exchange of obvious riddles on genitals, one in the hand of the initial compiler and the voice of a man named Robin, and the next in the second hand and a female persona named Rachel.60 Rachel concludes her final couplet with the obscene word that Davies omitted from his poem on the courtier and the 'cuntry swadd.' Then, on the verso of the same leaf and in the hand of the primary compiler, Davies begins to mock 'Byshope Fletcher \& my lady Baker': Mary Gifford, the widow of Sir Richard Baker. Davies gave the newly-weds the names of one of Shakespeare's Ovidian couples: 'the Romaine Tarquine' and 'Lucres.' Yet he also gave the bride the name of 'Lais,' after a Corinthian courtesan (in addition to repeatedly calling her a 'whore'). Juxtaposed as they are in this miscellany, the riddles on genitals emphasize the sexual misconduct alleged in the libels, and the libels in turn apply the sexual content of the erotic poems to the scandalous second marriage of a public figure.

Decades after he collected anti-courtly love poems at the Inns and consolidated them in his miscellany, another verse collector repoliticized these very same texts by adding to the Rosenbach manuscript early

59 Rosenbach MS 1083/15, pp. 67-73 ('A Libell against $\mathrm{m}^{\mathrm{r}}$ Bash//I know not how it comes to passé), 76-77 ('Byshope Fletcher $\&$ my lady Baker.//The pride of Prelacy w ${ }^{\text {ch }}$ now longe since'), 79 ('Cæcus the pleader hath a Lady wedd'), 79-80 ('Vppon the Astinian hilles the mountaine mare'), 80 ('ffollow the law \& let Primero goe'), 80-81 ('Maddam Olimpia rydeth in her coach'), 81 ('Holla my Muse leaue Cæcus in his greife'), 82-89 ('And doe you thinke I haue naught abode'); Sanderson, 'An Edition of an Early Seventeenth-Century Manuscript Collection of Poems,' 347-71, 377-82, 389433. See Poems of Sir John Davies, 171-79, 395-99.

60 Rosenbach MS $1083 / 15$, pp. 74 ('Riddle me Rachell whats this/that a ma[n] handles when he does pisse//It is a kind of pleasing sting'), 75 ('Now riddle me Robin $\&$ tell me thus much/Quid significant a Cut in Dutch//It is a wound $\mathrm{y}^{\mathrm{t}}$ nature giues'); Sanderson, 'An Edition of an Early Seventeenth-Century Manuscript Collection of Poems,' lx, 372-76. As Sanderson notes, the second of these obviously related verses is in a second hand. 
Stuart libels on another celebrity wedding. When the third collector to work on the manuscript added verse libels on this later high-profile marriage, he brought up to date the miscellany's account of political satire, and complicated the political associations of this manuscript's display of anti-courtly love poetry. This seventeenth-century verse collector copied some of the poems that attack the union of the Jacobean royal favorite Robert Carr, earl of Somerset, to, in the words of the copyist, ' $y$ e diuorced Lady of $y^{e} E$. of Essex $y^{t} /$ went for a mayd still his present wife,' which I analyze in Chapter 3.61 If the initial compilers of this Rosenbach manuscript politicized anti-courtly love poetry with late Elizabethan satires, the verse collector responsible for the Somerset libels repoliticized the genre and assimilated it to new contexts, shaped by unprecedented court scandal and corresponding developments in political verse. When he added these Somerset libels to the miscellany, he extended into the early Stuart period the manuscript's consistent objection to the second marriages of the rich and famous. He updated the political context of the volume's erotic verse. And he constructed a tense relationship between such poetry and at least certain members of the early Stuart court, making the anthology's anti-courtly love poetry look more anti-courtly than it ever had before.

Another verse collector politicized 'Nay pish, nay pewe' when he copied the poem in a miscellany now at the Folger Shakespeare Library and affiliated with one Joseph Hall (but not the famous satirist and bishop of Norwich). In the left margin beside the poem, he wrote: 'Against $\mathrm{M}^{\mathrm{rs}} /$ /Ioseph.' ${ }^{\prime} 2$ While it is possible that the copyist recorded the name of the poem's original subject in this heading, the probable date of his transcript casts some doubt on the compiler's reliability in this

61 Rosenbach MS 1083/15, pp. 139 ('Of S Robert Carr Earl of Somerset/\& y diuorced Lady of $y^{e}$ E. of Essex $y^{t} /$ went for a mayd still his present wife.//Lady chaynd to Venus Doue'; 'plants enow thence may ensue'), 140 ('On the late Earle of Somersett// ICVR, good monseir Carr'); Sanderson, 'An Edition of an Early Seventeenth-Century Manuscript Collection of Poems,' 698-702, 711-13.

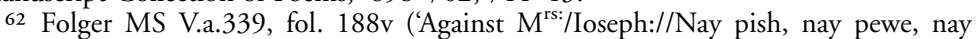
fayth, $\&$ will you? fie'). In his great study of the manuscript, Giles Dawson insisted that the Joseph Hall who signed his name of the flyleaf was 'not the Bishop of Norwich,' adding that 'the appearance of the signature does not suggest that Hall wrote anything else in the book and does suggest that it was written as late perhaps as 1700' ('John Payne Collier's Great Forgery,' Studies in Bibliography, 24 (1971), 3). Arthur Freeman and Janet Ing Freeman have most recently concurred (John Payne Collier: Scholarship and Forgery in the Nineteenth Century (New Haven: Yale University Press, 2004), 502). 
matter. He entered the poem just a few pages before two much later libels on the earl and countess of Somerset. ${ }^{63}$ Probably collecting and transcribing poems well into the seventeenth century then, this verse collector was more likely redeploying the poem against a woman whom the author had not intended to offend. Although it may offer little or no credible information regarding the poem's original context, this copy of 'Nay pish, nay pewe' uniquely exemplifies the interplay that developed between anti-courtly love poems and libels in miscellanies. For its transcriber's brief marginal note shows how little one needed to do to certain poems in order to exploit their libelous potential, which Chapters 3 and 4 demonstrate in regards to epigrams and a masque song that poets turned into libels. While this collector may not have quite turned 'Nay pish, nay pewe' into a libel, he did shame its sexualized speaker who, before he named her, endured no more shame than Marlowe's attractive Corinna. Furthermore, he politicized the poem by placing it where it resonates with the libels directed against the earl and especially the countess of Somerset. Rather like the libel on the countess that he transcribed, this unique copy of 'Nay pish, nay pewe' sexualizes and defames a specific woman. In this Folger miscellany, and like so many of the other mistresses of anti-courtly love poems, the mysterious Mrs. Joseph came to develop a relationship with the sexualized and publicly shamed target of an early Stuart libel.

In the first sustained study of early Stuart libels as literature (as opposed to straightforward political statements), Andrew McRae introduces the genre with a quotation from one of John Donne's weekly letters to his friend Sir Henry Goodyer, in which Donne addresses the 'multitude of libells' on the death of Sir Robert Cecil, earl of Salisbury. Donne wrote this letter while traveling on the continent, yet even there his party received a number of Cecil libels. He proposed, somewhat facetiously, that these libels on Cecil 'are so tastelesse and flat, that I protest to you, I think they were made by his friends.' For, he added:

when there are witty and sharp libels made which not onely for the liberty of speaking, but for the elegancie, and composition, would take deep root, and make durable impressions in the memory, no other way hath been thought so fit to suppresse them, as to divulge some course, and railing one: for when the

63 Folger MS V.a.339, fol. 193v ('Letchery [con] sulte $w^{t}$ h witchery howe to cause frigidety'; 'Some ar sett on mischeife soe, that they care not w they doe'). 
noise is risen, that libels are abroad, mens curiositie must be served with something: and it is better for the honour of the person traduced, that some blunt downright railings be vented, of which everybody is soon weary, then other pieces, which entertain us long with a delight, and love to the things themselves. ${ }^{64}$

Bad libels, Donne joked, actually benefited their traduced subject, for these forgettable poems quickly satisfied the curiosity of readers and kept them from seeking out better libels whose 'elegancie, and composition' would entertain and delight them. Donne considered the libels that succeeded his own classicist verse satires worthy of his attention; he admired the poetic qualities of some and acknowledged the political function of even the others. He did not embrace the new culture of libeling without qualification, however. He continued his letter to Goodyer by admitting, 'there may be cases, where one may do his Countrey good service, by libelling against a live man.' But, because their subject had died, he found the latest libels on Cecil 'unexcusable.' ${ }^{25}$ The compiler of Joseph Hall's Folger miscellany seems not to have shared Donne's objection to slandering the deceased; he copied two libelous epitaphs on Cecil. 66

As McRae suggests, Donne's aesthetic appreciation of libels articulates the sentiments of the manuscript verse collectors who gathered so many of these political verses among now-canonical poems in their miscellanies. Collectors preserved far more copies of libels in verse miscellanies than in manuscript books of exclusively topical or political documents; in other words, they deemed libels worthy of sharing space with the most exemplary lyric poetry of the English Renaissance. So they evidently considered libels more than mere records of political events or sentiments. The recent recognition of libels' place in literary culture has led scholars to engage the poetics, in addition to the politics, of these verses-an endeavor that tends to complicate their political significance. ${ }^{67}$ I propose that the acknowledgement of libels' popularity

${ }^{64}$ John Donne, Letters to Severall Persons of Honour (London: J. Flesher for Richard Marriot, 1651; Wing D1864), 89-90.

65 Donne, Letters, 90-91.

${ }^{66}$ Folger MS V.a.339, fol. 265r ('vpon Cicells death//Here lies Hobbinoll o ${ }^{\mathrm{r}}$ Shepherd whileare'; 'Here lyeth inrolled for wormes meate').

67 See "'Railing Rhymes": Politics and Poetry in Early Stuart England,' ed. Andrew McRae, Huntington Library Quarterly, 69/1 (March 2006). 
in verse miscellanies calls also for a corresponding reconsideration of the politics of the canonical poems that surround them, starting with anticourtly love poetry.

The next chapter begins this investigation in earnest by introducing the work of an anonymous seventeenth-century verse collector who related John Donne's most popular anti-courtly love poem, 'To his Mistress going to bed,' to a libel on, and a love lyric by, Sir Walter Ralegh. In order to explain the significance of his arrangement of these texts, I survey a series of answer-poems to Ralegh's love poems, as well as the work of scholars who have suggested that Donne was actually mocking Ralegh with his Ovidian love elegy. This verse collector offers some support for such a political reading of Donne's poem, but he also requires revising it. For he presented Donne's elegy as a parody not simply of Ralegh, but specifically of the love lyrics that Ralegh had employed for political purposes at the Elizabethan court. This verse collector joined others in establishing a striking relationship between Ralegh and Donne. Yet, as the chapter ultimately demonstrates, no two collectors constructed this relationship in the same way. The compilers of certain miscellanies presented Donne's Ovidian love elegy as something of an answer-poem to Ralegh. In the manuscript environments that they produced, Donne seems to mock Ralegh's poetry and politics. A collector responsible for other manuscripts, however, found poems by Ralegh and Donne to be perfectly compatible, and presented the two poets as exemplary authors of complementary love poems.

Chapter 3 deals in detail with a historical event that intensified the early Stuart vogue for the verse libel, and that dramatically recontextualized anti-courtly love poetry: the Overbury affair. This major Jacobean court scandal involved the 1613 divorce of a Catholic noblewoman, Frances Howard, from the son of a legendary militant protestant, Robert Devereux, third earl of Essex, on the grounds of impotence; Howard's prompt remarriage to King James' royal favorite Robert Carr, the new earl of Somerset; and the Somersets' 1616 conviction for conspiring to murder Carr's mentor, Sir Thomas Overbury, who had opposed their marriage. For reasons explored in the chapter, this explosive episode coincided with, and may have contributed to, an early wave of the dissemination of Donne's poetry beyond the tight circle of his coterie. Probably at the earl's request, Donne reluctantly considered dedicating a limited print edition of his poems to Somerset, after the poet aquired the 
secretary position that Overbury had vacated under duress. While Donne apparently avoided publishing his poems for Somerset, verse collectors soon intensified the scribal publication of Donne's poems. Moreover, they included his poems in books quite unlike the one that Donne contemplated presenting to Somerset, and placed them in relationships to the royal favorite that the author could not have approved. In their miscellanies, many of these collectors gathered Donne's poems among libels attacking the countess of Somerset-libels that, needless to say, Donne would not have included in his collection for her second husband. By associating Somerset libels with Donne's poems, the compilers of these miscellanies effectively turned Donne against his own patron. In this way the Overbury affair radically recontextualized Donne's poetry —as it did Overbury's own poem, 'A Wife,' and one of Francis Beaumont's anti-courtly love poems, 'Ad Comitissam Rutlandix.'

Chapter 4 proceeds to a scandal surrounding another Catholic woman: Prince Charles' proposed bride, Donna Maria Anna of Spain. By adding to their miscellanies libels on the marriage negotiations, otherwise known as the Spanish match, collectors of anti-courtly love poetry continued to assimilate the genre to a manuscript culture that disrespected prominent Catholic women. Yet Spanish match libels also began a new chapter in the history of early Stuart libels by introducing issues of male sexuality, through the figure of George Villiers, first duke of Buckingham. Like Somerset, Buckingham served as James' royal favorite, and had an emotionally intense, and possibly sexual, relationship with the king. Yet, unlike Somerset, Buckingham came under harsh censure for this purportedly erotic relationship in libels. By documenting this shift in the way that libelers criticized royal favorites, verse collectors marked a significant moment in both political history and the history of sexuality. One early Buckingham libel turned Ben Jonson's blessing of King James' senses (from the Buckingham-sponsored masque Gypsies Metamorphosed) into a provocative prayer that God keep those senses free from Buckingham's sexual advances. Several verse collectors juxtaposed this libelous representation of the royal bedchamber to Donne's 'To his Mistress going to bed.' In doing so, collectors hinted ironically at the love elegy's resonance with Ralegh, even as they associated Donne's poem with the libel's harsh censure of a more recent favorite.

Chapter 5 continues to focus on Buckingham, turning to his assassination, which most late Buckingham libels celebrate. By surrounding 
them with verses on the murdered duke and his assassin, collectors effectively completed the recontextualization of anti-courtly love poems with early Stuart politics. The chapter begins with collectors who sketched a progression of erotic royal favoritism from Ralegh to Buckingham, and who correspondingly positioned Donne's 'To his Mistress going to bed' as a tame predecessor to poetic criticisms of the later royal favorites. After opening with a professional miscellany featuring a decidedly radical political perspective, the chapter concludes with a future royalist collector who astonishingly misattributed a Buckingham libel to Donne, thereby associating its radical politics with the religious, satirical, and erotic poems that he also ascribed to Donne in his miscellany. This chapter also shows how collectors immersed other anti-courtly love poems by Donne, Beaumont, Carew, and Davies in the context of Buckingham's assassination. In the hands and books of these collectors, anti-courtly love poetry became caught up in the religious and political polarization that would ultimately constitute an early step toward the English civil wars.

After the civil wars, verse collectors would transform the politics of anti-courtly love poetry yet again, when critics of the protectorate put the genre to completely new purposes in printed miscellanies. The epilogue studies the first printed books to include the anti-courtly love poems that the Stationer's Company had prohibited the publisher of Donne's collected poems to print in 1633. In his 1654 anthology, The Harmony of the Muses, Robert Chamberlain claimed for the royalist cause all three of Donne's banned anti-courtly love poems: 'To his Mistress going to bed,' 'Loues Progresse,' and 'Loves War.' Chamberlain helped to make the printed miscellany of bawdy verse such an effective mode of announcing discontent with the protectorate that soon even nonroyalists adopted his model. In particular, Milton's nephew John Phillips and the publisher Nathaniel Brook, who had recently printed books in support of Cromwell, criticized recent developments in the protectorate when they included anti-courtly love poems in the two miscellanies that they printed in 1656. And the government responded by banning at least one of these miscellanies and fining its producers. Despite their innovativeness, these critics of the protectorate were extending what was by now a long tradition of verse collectors politicizing anti-courtly love poetry for their own purposes. Together, these collectors defined a literary genre that proved particularly adaptable while remaining pointedly political. 